\title{
PENGARUH MODEL PMBELAJARAN EXAMPLE NON EXAMPLE MELALUI ONLINE TERHADAP HASIL BELAJAR KOGNITIF SISWA MATERI SISTEM PERNPASAN MANUSIA KELAS XI SMA NEGERI 8 GOWA
}

\author{
Muhammad Wajdi \\ Pendidikan Biologi, FKIP, Univeritas Muhamadiyah Makassar \\ Email:muh.wajdi@unismuh.id ${ }^{3}$
}

\begin{abstract}
ABSTRAK
Penelitian ini merupakan penelitian eksperimen semu yang bertujuan untuk mengetahui pengaruh penggunaan model Example non Example terhadap hasil belajar kognitif Biologi siswa kelas XI MIA SMA Negeri 8 Gowa pada materi sistem pernapasan manusia. Pengumpulan data dilakukan melalui pemberian pretest dan posttest. Data dianalisis dengan statistik deskriptif dan statistik inferensial dengan bantuan SPSS (Statistical Product and Service Solutions) versi 24. diatas maka ditarik kesimpulan bahwa dikelas experiment rentang <75 terdapat 6 peserta didik memperoleh nilai dengan kategori kurang dengan persentase $20 \%$ pada rentang 75-83 terdapat 19 peserta didik memperoleh skor kategori cukup dengan persentase 63,3. Kemudian pada rentang 84-92 terdapat 5 peserta didik yang memperoleh kategori baik dengan nilai persentase 16,7. Sedangkan pada rentang 93-100 tidak ada peserta didik yang memperoleh skor dengan kategori baik sekali. Selanjutnya pada kelas kontrol dapat dilihat rentang $<75$ terdapat 8 peserta didik yang memperoleh skor dengan kategori kurang dengan memiliki persentase 60 pada rentang 75-83 terdapat 10 peserta didik dengan memperoleh skor dengan kategori cukup dengan persentase 33,3 kemudian pada rentang 84-92 terdapat 2 peserta didik yang memperoleh kategori baik dengan memiliki nilai persentase sebesar 6,7 kemudian pada rentang 93-100 tidak ada peserta didik yang memperoleh skor dengan kategori sangat baik
\end{abstract}

Kata kunci : Example Non Example, Hasil Belajar.

\section{ABSTRACT}

This research is a quasi-experimental research which aims to determine the effect of using the Example non Example model on the cognitive learning outcomes of students in class XI MIA SMA Negeri 8 Gowa on the material of the human respiratory system. Data collection was done by giving pretest and posttest. The data were analyzed with descriptive statistics and inferential statistics with the help of SPSS (versi) version 24. above, it was concluded that in the experimental class, the range $<75$, there were 6 students who scored in the category of less with a percentage of 20\% in the range 75-83 19 students obtained a sufficient category score with a percentage of 63.3. Then in the range 84-92 there are 5 students who get a good category with a percentage value of 16.7. Whereas in the range 93-100 there were no students who got a score in the very good category. Furthermore, in the control class it can be seen that the range $<75$ there are 8 students who get a score with a poor category by having a percentage of 60 in the range 75-83 there are 10 students by obtaining a score with a sufficient category with a percentage of 33.3 then in the range 84-92 there are 2 students who obtained a good category with a percentage value of 6.7 then in the range 93-100 there were no students who obtained a score in the very good category.

Keywords: Example Non Example, Learning Outcomes.

\section{Pendahuluan}

Kendala yang sering dihadapi oleh seorang guru dalam menyampaikan materi adalah penggunaan media pembelajaran yang kurang bervariasi. Hal tersebut, akan berdampak negatif bagi peserta didik sehingga tidak mempunyai minat untuk belajar dan akan berdampak pada hasil belajar peserta didik. Faktor yang turutmendukung hasil pendidikan adalah kualitas pembelajaran. Kualitas pembelajaran antara lain ditentukan oleh interaksi pendidik dengan peserta didik dan lingkungan. Dalam pembelajaran, interaksi antara pendidik dan peserta didik salah satu upaya membantu peserta didik untuk menguasai tujuantujuan pendidikan.Interaksi pendidik dapat berlangsung secara formal maupun non-formal baik dalam lingkungan keluarga, sekolah, maupun masyarakat. Pada keluarga interaksi pendidikan terjadi antara orang tua dan anak sedangkan di lingkungan sekolah interaksi terjadi antara guru dengan peserta didik.

Penggunaan model pembelajaran selama proses mengajar dapat membantu guru menyampaikan materi ke peserta didik. Tanpa media, komunikasi tidak akan terjadi dengan baik dan proses pembelajaran sebagai proses komunikasi juga tidak akan bisa berlangsung secara maksimal. Pembelajaran menempati posisi yang cukup penting sebagai salah satu komponen sistem pembelajaran bagi pendidik (guru). Bukuyang sering digunakan guru dalam proses mengajar di dalam kelas lebih banyak textbook, meskipun sudah ada variasi penambahan ilustrasi tetapi belum memberikan pengaruh yang cukup terhadap peningkatan minat baca peserta didik. Minat membaca yang rendah menyebabkan keaktifan dan 
hasil belajar menjadi rendah, selain itu kerumitan bahan ajar yang disampaikan semakin membuat peserta didik kurang tertarik untuk membaca buku pelajaran termasuk buku biologi. Peserta didik cenderung pasif dalam kegiatan pembelajaran apabila sarana prasarana belajar kurang mendukung. Untuk mengatasi hal tersebut (1), penggunaan media pembelajaran secara tepat dan bervariasi dapat mengatasi sikap pasif peserta didik ketika belajar biologi.

Pembelajaran Example Non Example adalah salah satu contoh-contoh model pembelajaran yang menggunakan media. Model dalam pembelajaran merupakan sumber yang digunakan dalam proses belajar mengajar, memanfaat model ini adalah untuk guru dapat membantu dalam proses belajar mengajar, mendekati situasi dengan keadaan yang sesungguhnya. Dengan model, diharapkan proses belajar dan mengajar lebih komunikatif dan dapat menganalisis gambar tersebut menjadi sebuah bentuk deskripsi singkat mengenai apa yang ada didalam gambar tersebut.

Model pembelajaran Example Non Example menggunakan gambar yang dapat melalui proyektor ataupun yang paling sederhana adalah gambar, gambar yang gunakan harus jelas dan kelihatan dari jarak jauh, sehingga peserta didik yang berada paling belakang juga dapat melihat dengan jelas.

"Example dan Non Example adalah model pembelajaran yang menggunakan contoh-contoh melalui kasus atau gambar yang relevan dengan kompetensi dasar. Melalui model pembelajaran ini peserta didik diharapkan dapat memilih dan menyesuaikan dengan contoh-contoh yang ada melalui gambar tersebut sehingga diharapkan dapat meningkatkan hasil belajar peserta didik (2).

Model pembelajaran Example Non Example juga ditunjukkan untuk mengajarkan siswa dalam belajar memahami dan menganalisis sebuah konsep, konsep pada umumnya dipelajari melalui dua cara yaitu pemahaman dan definisi. Model Example Non Example adalah model yang dapat digunakan untuk mengajarkan definisi konsep.

Banyak model pembelajaran yang telah dikembangkan oleh guru pada dasarnya untuk memberikan kemudahan kepada siswa untuk memahami dan menguasai suatu pembelajaran atau materi tertentu. Pengembangan model pembelajaran tergantung dari penyesuaian antara mata pelajaran dengan model pembelajaran. Sehingga, setiap model pembelajaran tidak diyakini sebagai model pembelajaran yang paling baik, semua tergantung situasi dan kondisi (3).

Ada banyak model pembelajaran yang berkembang untuk membantu siswa untuk berfikir kreatif dan produktif. Bagi guru model-model ini penting merancang kurikulum. Model pembelajaran harus dianggap sebagai kerangka kerja structural yang dapat digunakan sebagai pemandu untuk mengembangkan lingkungan dan aktivitas belajar yang kondusif.

Menurut joyce dan Weil. Model pembelajaran adalah suatu rencana atau pola yang dapat digunakan untuk membentuk kurikulum, merancang bahan-bahan pembelajaran dan membimbing pembelajaran dikelas agar lebih konduktif (4).

Model pembelajaran dapat dijadikan pola pilihan, artinya para guru boleh memilih model pembelajaran yang sesuai dan efisien untuk mencapai tujuan pendidikan.

Model pembelajaran adalah prosedur sistematis saat mengorganisasikan pengalaman saat belajar untuk meraih tujuan pembelajaran. Dan dapat diartikan juga sebagai pendekatan yang dipakai dalam aktivitas pembelajaran. Guru yang kompeten adalah guru yang dapat mengelola program belajar mengajar. Pengelolaan disini mempunyai makna yang luas yang mengangkut bagaimana seorang guru dapat menguasai keterampilan dasar mengajar, layaknya membuka dan menutup pembelajaran, menjelaskan mengkreasi media, mengajukan pertanyaan,

Model pembelajaran merupakan model pembelajaran yang pola yang digunakan sebagai pedoman dalam merencanakan proses pembelajaran didalam kelas maupun tutorial. Model pembelajaran mengacu pada pendekatan yang akan digunakan, termasuk dalam tujuan-tujuan pembelajaran, tahapantahapan dalam tujuan pembelajaran, lingkungan pembelajaran, dan pengelolaan kelas (7). Model pembelajaran dapat didefinisikan sebagai kerangka konseptual yang melukiskan prosedur sistematis dalam mengorganisasikan pengalaman belajar untuk mencapai suatu tujuan pembelajaran. Melalui model pembelajaran guru dapat membantu peserta didik mendapatkan informasi, ide keterampilan, cara berpikir, dan mengekspresikan ide. Model pembelajaran berfungsi pula sebagai pedoman bagi para perancang pembelajaran dan para guru merencanakan aktivitas proses belajar mengajar.

\section{Metode Penelitian}

Jenis penelitian yang digunakan dalam penelitian ini adalah eksperimen semu (quasi eksperimen) yang bertujuan untuk mengetahui apakah ada pengaruh penggunaan model pembelajaran Example Non Example terhadap hasil belajar siswa kelas XI SMA Negeri 8 Gowa.

Desain penelitian yang digunakan pada penelitian ini adalah Pretest Posttest Control Group Design yaitu eksperimen yang melibatkan dua kelompok

Tabel 3.1 Model Desain Penelitian〉

\begin{tabular}{cccc}
\hline Kelas & Pretest & Perlakuan & Posttest \\
\hline Ekperimen & $\mathrm{O}_{1}$ & $\mathrm{X}$ & $\mathrm{O}_{2}$ \\
Kontrol & $\mathrm{O}_{3}$ & $\mathrm{C}$ & $\mathrm{O}_{4}$ \\
\hline Keterangan: & \\
$\mathrm{O}_{1}:$ Pretest pada kelas eksperimen & \\
$\mathrm{O}_{2}:$ Posttest pada kelas eksperimen & \\
$\mathrm{O}_{3}$ : Pretest pada kelas control & \\
$\mathrm{O}_{4}$ : Posttest pada kelas kontrol & \\
$\mathrm{X} \quad$ : Kelas eksperimen menggunakan & model \\
\multicolumn{2}{l}{ pembelajaran Example Non Example }
\end{tabular}


C : Kelas kontrol tidak menggunakan model pembelajaran Example Non Example

Jenis data yang digunakan dalam penelitian ada dua yaitu data kualitatif. Sumber data dari penelitian terbagi atas dua yaitu Data primer, termasuk data yang langsung dikumpulkan oleh peneliti dari sumbernya di lapangan. Sedangkan, Sumber data sekunder, yaitu data yang dikumpul langsung oleh peneliti sebagai penunjang dari sumber pertama. Instrumen penelitian yang digunakan dalam penelitian tersebut adalah berupa soal pilihan ganda sebanyak 35 soal, untuk mengukur hasil belajar kognitif biologi siswa pada materi sistem pernapasan manusia. Dan LKPD lembar kerja peserta didik yang sesuai dengan tahapan pembelajaran. Adapun teknik pengumpulan data yang peneliti gunakan adalah data diperoleh dari pre-test dan post-test yaitu berupa soal pilihan ganda jumlah soal sebanyak 35 butir soal dengan lima pilihan jawaban. Pret-test gunakan untuk melihat atau mengetahui beberapa besar pengetahuan awal siswa. Sedangkan post-test adalah tes yang dilakukan setelah dilakukan perlakuan untuk melihat hasil belajar siswa.

Analisis data pada penelitian ini dilakukan dengan menggunakan analisis statistic deskriptif dan statistic inferensial yaitu analisis data mengenai hasil posttest dan pretest kelas eksperimen dan kelas kontrol. Kemudian analisis data mengenai pengaruh model pembelajaran Example Non Example terhadap hasil belajar siswa materi sistem pernapasan manusia.

Table 3.4: Kriteria Hasil Belajar Siswa

\begin{tabular}{ccc}
\hline interval Nilai & Predikat & Keterangan \\
\hline $93-100$ & A & Sangat Baik \\
$84-92$ & B & Baik \\
$75-83$ & C & Cukup \\
$<75$ & D & Kurang \\
\hline
\end{tabular}

Kemendikbud (2017)

Kriteria hasil belajar tersebut diatas memiliki batas nilai paling rendah ditetapkan pada awal tahun ajaran baru yang sering disebut dengan kriteria ketuntasan minimal (KKM) hasil belajar.

Tabel 3.4 Standar kriteria ketuntasan minimal

\begin{tabular}{cc}
\hline Nilai & Kategori \\
\hline$>75$ & Tuntas \\
$<75$ & Tidak tuntas \\
\hline
\end{tabular}

\section{PEMBAHASAN}

\subsection{Hasil Pengembangan}

Hasil penelitian merupakan data yang diperoleh setelah melakukan sebuah penelitian. Data tersebut merupakan data hasil posttest dari kelas eksperimen yang menggunakan model pembelajaran Example non Example dan kelas kontrol yang menggunakan model pembelajaran konvensional, untuk melihat pengaruh model Example non Example terhadap hasil belajar siswa kelas XI materi sistem pernapasan manusia.

Berikut ini merupakan data hasil posttest pada siswa XI MIA 2 sebagai kelas eksperimen yang menggunakan model pembelajaran Example non Example dan XI MIA
3 sebagai kelas kontrol yang menggunakan model konvensional.

Tabel 4.1 pengolah data statistic deskriptif skor hasil tes belajar (pretest dan post-test)

\begin{tabular}{ccc}
\hline Statistic & \multicolumn{2}{c}{ Kelas eksperimen } \\
& Pret-test & Post-test \\
\hline Skor sampel & 30 & 30 \\
Skor Tertinggi & 77 & 90 \\
Skor Terendah & 43 & 66 \\
Mean & 55.37 & 79.70 \\
Range & 34 & 24 \\
\hline
\end{tabular}

Terdapat pada kelas eksperimen dan kelas kontrol masing-masing memiliki 30 sampel. Pada kelas eksperimen yang diberi perlakuan model Example Non Example memperoleh data Pretest skor tertinggi yaitu 77 dan skor terendah sebesar 43. Sedangkan Post-Test, skor tertinggi 90 dan skor terendah 66. Adapun nilai rata-rata (mean) Pret-Test sebesar 55.37 dan post-test sebesar 79.70, kemudian (Range) pada print-test sebesar 34 sedangkan post-test sebesar 24.

Tabel 4.2 pengolah data statistic deskriptif skor hasil tes belajar (pretest dan post-test).

\begin{tabular}{ccc}
\hline Statistic & \multicolumn{2}{c}{ Kelas kontrol } \\
& Pret-test & Post-test \\
\hline Skor sampel & 30 & 30 \\
Skor Tertinggi & 67 & 87 \\
Skor Terendah & 37 & 43 \\
Mean & 49.80 & 70.87 \\
Range & 30 & 44 \\
\hline
\end{tabular}

Selanjutnya pada kelas kontrol yang tidak diberi perlakuan Example Non Example memperoleh skor tertinggi 67, dan skor terendah sebesar 37, sedangkan Post-Test skor tertinggi yang diperoleh sebesar 87 sedangkan terendah sebesar 43, adapun nilai rata-rata (mean) Pret-Test sebesar 49.80 sedangkan Post-Test sebesar 70.87, sedangkan (range) pada Pret-Test sebesar 30 sedangkan pada Post-Test sebesar 44.

Adapun skor tes hasil biologi siswa setelah diberi perlakuan (post-test) kemudian dikelompokkan kedalam kriteria hasil belajar siswa, dimana dalam kriteria ini terdapat interval nilai yang akan menunjukkan kategori nilai yang diperoleh, dimana terdiri dari kategori sangat baik, baik, cukup, atau kurang, maka diperoleh distribusi skor frekuensi dan persentase pada tabel 4.3.

Tabel 4.3 Distribusi Frekuensi Dan Persentase Skor Hasil Belajar Biologi Siswa Pada Kelas Eksperimen dan Kelas Kontrol Setelah Perlakuan (post-test)

\begin{tabular}{cccc}
\hline $\begin{array}{c}\text { Interval } \\
\text { Skor }\end{array}$ & Kategori & \multicolumn{2}{c}{ Kelas Experimen } \\
Frekuensi & Persente \\
\hline $93-100$ & Sangat baik & 0 & 0 \\
$84-92$ & Baik & 5 & 16.7 \\
$75-83$ & Cukup & 19 & 63.3 \\
$<75$ & Kurang & 6 & 20 \\
& Jumlah & $\mathbf{3 0}$ & $\mathbf{1 0 0}$ \\
\hline
\end{tabular}

Pada tabel 4.3 diatas maka ditarik kesimpulan bahwa dikelas experiment rentang $<75$ terdapat 6 peserta didik memperoleh nilai dengan kategori kurang dengan persentase $20 \%$ pada rentang 75-83 terdapat 19 
peserta didik memperoleh skor kategori cukup dengan persentase 63,3. Kemudian pada rentang 84-92 terdapat 5 peserta didik yang memperoleh kategori baik dengan nilai persentase 16,7. Sedangkan pada rentang 93-100 tidak ada peserta didik yang memperoleh skor dengan kategori baik sekali.

Tabel 4.4 Distribusi Frekuensi Dan Persentase Skor Hasil Belajar Biologi Siswa Pada Kelas Eksperimen dan Kelas Kontrol Setelah Perlakuan (post-test)

\begin{tabular}{cccc}
\hline $\begin{array}{c}\text { Interval } \\
\text { Skor }\end{array}$ & \multirow{2}{*}{ Kategori } & \multicolumn{2}{c}{ Kelas control } \\
& & Frekuensi & Presentase \\
\hline $93-100$ & Sangat baik & 0 & 0 \\
$84-92$ & Baik & 2 & 6.7 \\
$75-83$ & Cukup & 10 & 33,3 \\
$<75$ & Kurang & 18 & 60 \\
& Jumlah & $\mathbf{3 0}$ & $\mathbf{1 0 0}$ \\
\hline
\end{tabular}

Selanjutnya pada kelas kontrol dapat dilihat rentang $<75$ terdapat 8peserta didik yang memperoleh skor dengan kategori kurang dengan memiliki presentse 60 pada rentang 75-83 terdapat 10 peserta didik dengan memperoleh skor dengan kategori cukup dengan prentase 33,3 kemudian pada rentang 84-92 terdapat 2 peserta didik yang memperoleh kategori baik dengan memiliki nilai presentse sebesar 6,7 kemudian pada rentang 93-100 tidak ada peserta didik yang memperoleh skor dengan kategori sangat baik.

Adapun data ketuntasan hasil belajar peserta didik pada metri sistem pernapasan mansuia setekah diberikan posttest, dapat dilihat dari data dibawah ini.

Tabel 4.4 Data Ketuntasan Hasil Belajar (posttest) Kelas Eksperimen Dan Kelas Kontrol.

\begin{tabular}{cccc}
\hline \multirow{2}{*}{ Nilai } & \multirow{2}{*}{ Kategori } & \multicolumn{2}{c}{ Kelas Experimen } \\
& Frekuensi & Persentase \\
\hline $75-100$ & Tuntas & 26 & 86,7 \\
$<75$ & Tidak tuntas & 4 & 13,3 \\
& Jumlah & 30 & 100 \\
\hline
\end{tabular}

Berdasarkan tabel 4.3 dapat dilihat bahwa persentase ketuntasan posttest hasil belajar biologi pada kelas eksperimen dengan menggunakan model Example Non Example dengan jumlah siswa 30 menunjukkan bahwa 26 orang siswa termasuk kriteria tuntas dengan persentase mencapai $86,7 \%$ sedangkan siswa yang berada pada kategori tidak tuntas atau hasil belajar yang dicapai berada dibawah KKM yaitu 4 orang dengan persentase mencapai $13,3 \%$.

Tabel 4.5 Data Ketuntasan Hasil Belajar (posttest) Kelas Eksperimen Dan Kelas Kontrol.

\begin{tabular}{cccc}
\hline Nilai & Kategori & \multicolumn{2}{c}{ Kelas Kontrol } \\
& & Frekuensi & Persentase \\
\hline $75-100$ & Tuntas & 13 & 43,4 \\
$<75$ & Tidak tuntas & 17 & 56,6 \\
& Jumlah & 30 & 100 \\
\hline
\end{tabular}

Sedangkan pada kelas kontrol menunjukkan bahwa 13 orang siswa termasuk kategori lulus dengan persentase mencapai $43,4 \%$ sedangkan pada kategori tidak tuntas atau hasil belajar yang dicapai yang berada dibawah KKM yaitu 17 orang dengan persentase $56,6 \%$.

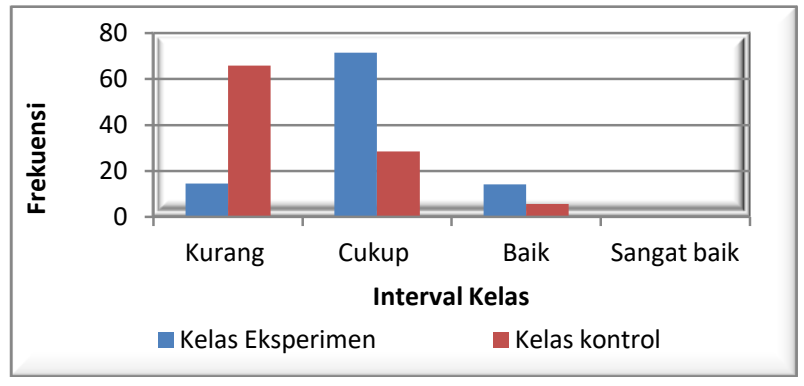

Pada Grafik 4,1 diatas maka ditarik kesimpulan bahwa dikelas experiment rentang $<75$ terdapat 6 peserta didik memperoleh nilai dengan kategori kurang dengan persentase $20 \%$ pada rentang 75-83 terdapat 19 peserta didik memperoleh skor kategori cukup dengan persentase 63,3. Kemudian pada rentang 84-92 terdapat 5 peserta didik yang memperoleh kategori baik dengan nilai persentase 16,7. Sedangkan pada rentang 93-100 tidak ada peserta didik yang memperoleh skor dengan kategori baik sekali. Selanjutnya pada kelas kontrol dapat dilihat rentang <75 terdapat 8peserta didik yang memperoleh skor dengan kategori kurang dengan memiliki presentse 60 pada rentang 75-83 terdapat 10 peserta didik dengan memperoleh skor dengan kategori cukup dengan prentase 33,3 kemudian pada rentang 8492 terdapat 2 peserta didik yang memperoleh kategori baik dengan memiliki nilai presentse sebesar 6,7 kemudian pada rentang 93-100 tidak ada peserta didik yang memperoleh skor dengan kategori sangat baik.

Sebelum menguji hipotesis, maka terlebih dahulu dilakukan uji persyaratan analisis terhadap data penelitian. Uji persyaratan yang pertama adalah uji normalitas. Pengujian normalitas bertujuan untuk mengetahui apakah populasi berdistribusi normal. Uji normalitas yang digunakan yaitu dengan menggunakan uji SPSS 24 dengan uji Normality Test (KolmogorovSmirnov).

Terdapat hasil data dari uji normalitas yang dilakukan, di dapatkanlah hasil data yang diperoleh dari sampel berdistribusi normal. sesudah dilakukannya hasil normalitas tersebut, selanjutnya melakukan tes uji homogenitas yang bertujuan untuk melihat tinggi dari kesamaan variabel antara dua kelompok variabel yaitu kelompok variable eksperimen dan kelompok variabel kelas kontrol. Jika dikatakan normal homogen apabila nilai signifikansi diatas dari (sig)> 0,05. Uji homogenitas terdapat buah variabel yang dapat diperoleh melalui uji Homogeneity Of Variance Test dengan bantuan aplikasi SPSS 24. Berdasarkan hasil uji prasyarat analisis data dari dua kelompok yaitu kelas eksperimen dengan menggunakan model example non example dan kelas kontrol dengan menggunakan pembelajaran konvensional, diketahui bahwa kedua kelas memiliki sampel yang berdistribusi normal dan kelas tersebut sifatnya homogen dapat dilakukan Uji hipotesis. 


\subsection{Pembahasan}

Penelitian ini merupakan jenis penelitian eksperimen semu atau quasi eksperimen tujuan dilakukan penelitian ini adalah untuk mengetahui ada, atau tidaknya pengaruh penggunaan model pembelajaran Example non Example terhadap hasil belajar biologi siswa materi sistem pernapasan manusia kelas XI SMA Negeri 8 Gowa. Penelitian dilakukan di SMA Negeri 8 Gowa dengan sampel XI MIA 2 sebagai kelas eksperimen dan kelas XI MIA 3 sebagai kelas kontrol. Perlakuan diberikan pada kelas eksperimen yang model pembelajaran Example Non Example sedangkan pada kelas kontrol adalah pembelajaran konvensional. Kedua kelas tersebut diberi tes pengetahuan awal berupa soal (pre-test) dan soal tes akhir (post-test)

Pada kelas eksperimen penerapan model pembelajaran Example Non Example peserta didik menjadi lebih aktif dan antusias dalam proses pembelajaran. Banyak terjadi interaksi antara peserta didik dengan guru maupun interaksi antara peserta didik dengan peserta didik lainnya. Semua peserta didik saling berdiskusi bertukar pendapat dengan kelompoknya masing-masing sehingga tidak ada pasif. Hal ini mengakibatkan semua peserta ikut berpartisipasi saat proses pembelajaran berlangsung. Suasana yang terjadi pada saat proses belajar berlangsung pun lebih menyenangkan dan kondusif sehingga peserta didik menjadi mudah menerima pembelajaran yang telah disampaikan. Dikelas yang telah diterapkan model Example Non Example peserta didik saling bertukar pikiran dan pendapat dengan kelompoknya masingmasing, serta melatih mereka untuk mampu menganalisis gambar-gambar contoh dari materi yang sudah disiapkan oleh guru. Dengan model pembelajaran Example Non Example ini peserta didik menjadi aktif dan proses pembelajaran terasa lebih menyenangkan, dan peserta didik menjadi aktif dalam belajar dan pembelajaran pun terasa lebih menyenangkan dan peserta didik tidak mudah menjadi bosan, namun tetap menjadi tujuan pembelajaran yang sudah ditetapkan sehingga dapat meningkatkan hasil belajar peserta didik.

Sedangkan pada kelas kontrol yang tidak menggunakan model pembelajaran Example Non Example, bahwa tidak semua peserta didik ikut aktif pada saat proses pembelajaran berlangsung. Banyak peserta didik yang tidak aktif dalam menanggapi maupun menyimpulkan materi yang telah dibahas, hanya sebagian peserta didik yang pandai saja yang aktif berbicara atau menanggapi pertanyaan. Sedangkan yang lain hanya diam dan mendengarkan apa yang disampaikan disaat proses pembelajaran berlangsung, dan malu-malu untuk memberikan tanggapan. Suasana dalam kelas pun menjadi sedikit membosankan dan corak interaksi. Akibatnya tujuan pembelajaran tidak

Berdasarkan hasil analisis statistic deskriptif untuk data posttest pada kelas XI MIA 2 sebagai kelas eksperimen yang ajarkan dengan menggunakan model Example Non Example, rata-rata hasil belajar yang diperoleh sebesar 79,70 sedangkan pada kelas XI MIA 3 sebagai kelas eksperimen yang diajarkan menggunakan model konvensional rata-rata hasil belajar yang diperoleh sebesar 70,87. Dari data tersebut menunjukkan bahwa hasil belajar siswa pada kelas yang diajarkan dengan menggunakan model Example non Example lebih tinggi dibandingkan dengan hasil belajar siswa pada kelas yang diajarkan dengan menggunakan pembelajaran konvensional. Hal ini dikarenakan model pembelajaran Example non Example merupakan model pembelajaran yang menggunakan gambar sebagai media pembelajaran, dan metode pembelajaran yang menggunakan contoh-contoh, contoh-contoh dapat dari gambar yang relevan. Sebagaimana penelitian yang dilakukan oleh (4) membuktikan bahwa rata-rata hasil belajar kelas eksperimen dengan menggunakan model Example non Example lebih baik dibandingkan dengan rata-rata hasil belajar kelas kontrol dengan menggunakan pembelajaran konvensional.

Berdasarkan kategori tuntas dan tidak tuntas, maka persentase ketuntasan hasil belajar setelah diberikan perlakuan (Post-test) pada kelas eksperimen yang diajar dengan menggunakan model Example non Example diperoleh hasil 85,7\% kategori tuntas. Sedangkan pada kelas kontrol yang diajarkan dengan menggunakan pembelajaran konvensional memperoleh hasil 34,2\% kategori tuntas. Berdasarkan hal tersebut menunjukkan bahwa model Example non Example memiliki pengaruh terhadap hasil belajar siswa

Untuk membuktikan apakah ada pengaruh model Example non Example terhadap hasil belajar biolog peserta didik pada materi sistem pernapasan manusia, maka dilakukannya tes uji hipotesis. Akan tetapi sebelum melakukan uji hipotesis terlebih dahulu melakukan uji prasyarat yaitu uji normalitas dan uji homogenitas.

Berdasarkan hasil uji prasyarat yang dinyatakan bahwa untuk data pada kelas eksperimen dan kelas kontrol itu berasal dari populasi berdistribusi normal dan kedua kelompok berasal dari varians yang selalu homogen, sehingga akan dilakukan tipe uji hipotesis dan untuk menggunakan uji independent sample T-Test yang selalu menunjukkan bahwa pada model pembelajaran Example non Example memiliki pengaruh terhadap hasil belajar biologi siswa. Hal ini dibuktikan dengan peroleh nilai $p=0,001$. Dimana nilai signifikansi $=0,00$ lebih dari 0,05 . Maka dengan demikian dapat dinyatakan bahwa hipotesis diterima, sehingga kesimpulan adalah terdapat pengaruh terhadap model Example non Example terhadap hasil belajar kognitif siswa materi sistem pernapasan manusia kelas XI SMA Negeri Gowa.

Jadi dapat disimpulkan bahwa jawaban dari permasalahan yang ada adalah "ada pengaruh model pembelajaran Example Non Example terhadap hasil belajar siswa kelas XI SMA Negeri 8 Gowa"

Hal ini dapat dilihat pada nilai rata-rata hasil belajar peserta didik yang menggunakan model Example Non Example lebih tinggi dari pada hasil belajar peserta didik yang tidak menggunakan model 
pembelajaran Example Non Example. Demikian dapat diambil kesimpulan bahwa dengan menerapkan model pembelajaran Example Non Example memiliki pengaruh terhadap hasil belajar peserta didik karena dapat meningkatkan hasil belajar peserta didik kelas xi sma negeri 8 Gowa.

\section{Kesimpulan}

Berdasarkan hasil penelitian dan pembahasan, maka dapat disimpulkan sebagai berikut:

1. Penerapan model pembelajaran Example non Example memiliki pengaruh terhadap terhadap hasil belajar siswa. Dimana adanya peningkatan hasil belajar siswa kelas XI SMA Negeri Gowa pada materi sistem pernapasan manusia yang dapat dilihat pada hasil analisis dan deskriptif yaitu menunjukkan bahwa pada kelas eksperimen yang diterapkan model Example non Example lebih tinggi dengan rata-rata $79 \%$ daripada kelas kontrol yang tidak diterapkan model pembelajaran Example non Example dengan nilai rata-rata $70 \%$

2. Berdasarkan analisis inferensial, terdapat pengaruh penggunaan model Example non Example terhadap hasil belajar kognitif siswa kelas XI SMA Negeri Gowa Pada Materi Sistem Pernapasan Manusia. Hal ini berdasarkan pada data hasil uji hipotesis melalui independent sample T-Test dengan nilai $\mathrm{p}=0,001<\mathrm{a}=0,005$. Hal ini menunjukkan bahwa hasil belajar siswa dengan menggunakan model Example non Example lebih tinggi dibandingkan dengan pembelajaran konvensional

\section{Daftar pustaka}

1 Ismi, Utariyanti, dkk 2015. Pengembangan Media Pembelajaran Berbasis Komik dalam Materi Sistem Pernapasan pada Siswa Kelas VIII. Mts Muhammadiyah Malang. FKIP Universitas Muhammadiyah Malang. E-Jurnal. Vol : 1 No. 3. ISSN : 2442-3750.

3 Huda, Miftahul. 2019. Model-Model Pengajaran Dan Pembelajaran. Yogyakarta : Pustaka Pelajar

4 Hamza B. Uno, M.Pd dan Nurdin Muhammad. 2012. Belajar dengan Pendekatan PAILKEM. Jakarta : Bumi Aksara

5 Kemendikbud. 2017. Panduan Penilaian oleh Pendidik dan Satuan Pendidikan. Jakarta

6 Rusman. 2014. Model-model Pembelajaran (Mengembangkan Profesionalisme Guru). Jakarta : Raja Grafindo Persada

7 Suprijono, Agus. 2014. Cooperatif Learning Teori dan Aplikasinya PAILKEM. Yugyakarta : Pustaka Pelajar. 